\title{
Security-Development Nexus and the Discourse of Fragile States
}

\section{Syaiful Anam}

School of Political Science and International Studies, Queensland University, Australia

Email:s.anam16@ymail.com

\begin{abstract}
Abstrak
Tulisan ini akan mengkaji masalah mendasar dari wacana negara rapuh. Menggali mengenai kerangka Pengembangan Keamanan Perhubungan untuk meyakinkan agenda kebijakan Negara dan pembangunan bangsa di negara rapuh. Tulisan ini berpendapat bahwa Pengembangan Keamanan Perhubungan mendasari proyek pembangunan negara bangsa di "negara rapuh" yang dengan jelas membuat ketidakamanan dan membuat ulang ketidaksetaraan dan kemiskinan daripada menghasilkan keamanan dan kesetaraan seluruh masyarakat.

Kata kunci: Pengembangan Keamanan Perhubungan, Negara Rapuh, Pembangunan negara bangsa.
\end{abstract}

\begin{abstract}
This paper will examine the underlying problem within the discourse of fragile state. It will be investigating the framework of security-development nexus used to justify the policy agenda of state and nation building in fragile states. It argues that the security development nexus underpinning the project of nation/state-building in 'fragile states' obviously create insecurity and (re)produce inequality and poverty, rather than generate security and equality throughout society.

Key words: Security development nexus, fragile states, state/nation building.
\end{abstract}

\section{INTRODUCTION}

This paper will be investigating the problem revolves around the discourse of fragile states. It will particularly focus on the notion of security development nexus adheres within the policy agenda of state/ nation building or state formation in fragile states. Given that the security (both in term of state and human security) and humanitarian aid are paramount for states seeking to arise from its fragility, it is too often that state building's policies aimed at tackling these problems are addressed through certain measures dominated by efforts to institutionalize the liberal peace (Wallis, 2012). The liberal agenda of state building, on the one hand, seeks to intertwine security and development issues as its priority. Yet, on the other hand, it is precisely creating insecurity and (re)producing inequality, rather than creating security and welfare throughout society. This is, for instance, demonstrated through the case of Haiti in which the process of state building in term of consolidating the modern liberal state has resulted a condition of domination and subordination upon Haitian (Shah, 2009). Similarly, the liberal state building and economic development agendas have created the economic marginalization, insecurity and inequality as well as maintained the perpetuation of clientelism policies in African countries. In fact, for countries 
such as Ethiopia, Zimbabwe, and South Africa, the liberal agenda brought by international bodies has led them to face social, economic, and political instability and vulnerability (Carmody, 2007, quoted in Aime, 2008)

This paper argues that the security development nexus underpinning the project of nation/statebuilding in 'fragile states' obviously create insecurity and (re)produce inequality and poverty, rather than generate security and equality throughout society. To substantiate this proposition, this essay will examine the notion of security development nexus and the discourse around fragile states. This will problematize the spatial-temporal framework underpinning the security development nexus in framing and analyzing the problem in fragile states. This essay will not be focused on a specific case study of fragile states.

Instead, it will explore and combine several critical insights regarding the discourse of fragile states and the flaws of security-development nexus. This essay then will be structured into three main parts. The first part of the essay will particularly be an attempt to understanding the discourse of fragile states. The next part of the essay will be then exploring the notion of security-development nexus. Before concluding this essay, the third part will critically examine insights aimed at criticizing security-development nexus in term of liberal state-building project in fragile states. It is mainly to show that the notion of security development nexus has failed to provide useful insight on the problem of security and humanitarian challenges in order to resolve the problem of fragile states.

\section{ANALYSIS}

\section{UNDERSTANDING FRAGILE STATES}

The discourse of fragile states becomes an international attention as the consequence of at least four interconnected issues: a realization of development community aimed at strengthening state policies and institutions; the potential of weak states as global threat; the operation of the United Nations peacebuilding in post-war states; and the impact of the Cold War upon contemporary security agenda.
Although the perspective of fragile states diverges in term of why and in what context the discourse emerged, majority conceives that threat emerge from within the state and thereby state is the only instrument can solve its fragility, not the market (Wennmann, 2009).

States, by many development agencies and donors since the mid-1990s, have been regarded as the catalyst of development. States with 'a good' policies and institutions hence will double the effect of economic aids to the attempts of fighting the poverty and insecurity. This insight is linked to a pre-existing discourse in social science associated with the work of Theda Skocpol in 'Bringing the State Back in' in which emphasize the state capacity, strength, and weakness as well as its potential role as 'development catalysers' (Skocpol, quoted in Wennmann, 2009). Hence, it can be argued that enhancing the impact of economic aid to effectively tackle the problem of poverty will need robust state's institutions and policies. Consequently, states having no these criteria are regarded as fragile state and accordingly they would entail the international intervention to reform their capacities and institutions.

The international policies concern on fragile states also emerged as the consequence of the potential threat of a weak state to economic stability. The event of the Asian financial crisis on 1997 and 1998 showed that states adopting financial liberalization without appropriate regulatory framework as well as with corrupt and weak governance posed threat to the global economy and regional stability. Accordingly, the crisis addressed the need to enhance the resilience of the state capacity and governance in competing in the globalization era (Wesley, 2008). Failed to do so will lead states to fall into fragility and ultimately give space for breeding global terrorist network and criminal which threat both national and international security. The tragedy of $9 / 11$ had proven that international threat was not coming from the state actors, but instead posed by non-state actors who flourished within fragile states which lack of social and political security (Peace Security and Development Network, 
2009).

The emergence of discourse on fragile states also has a correlation with the context of the United Nations operation within peacebuilding process. Former UN Secretary General, Boutros Boutros-Ghali, had proposed an idea in the 1992's Agenda for Peace aimed at strengthening and solidifying peace in post-conflict peacebuilding process. It stressed on the importance of consolidating peace after the war, most importantly in term of positive peace, preventing new conflicts, and covering both remedial and preventive purposes. Moreover, the idea of peacebuilding evolved to the attempt of establishing a democratic state, the rule of law, a liberal market economy, as well as promoting human rights, good governance, and alleviating the military budget (Paris, 2002). These criteria furthermore become a new type of political conditionality of international engagement in fragile states or conflict states.

In addition, the Cold War had given significant impact that left the states with political fragmentation and social division. The great rivalry and contestation between two great powers, the US and Soviet Union (and their allies), in term of proxy war, provided the military assistant and economic support to state actors, non-state actors and guerilla movements such as in Angola, Afghanistan, Egypt, Vietnam, Korea, and Latin America. By the end of the Cold War, many of these states that were aligned with great power were trapped into a divisive politics and belong to fragile states. The social division and political instability within states in post-cold war era (as the cause of authoritative regime and the conflict between ruling government and opposition) then led, in many instances, to the conduct of genocide, human massacre, ethnic cleansing, and crime against humanity. This situation shifted the concern of security from the statecentered to human-centered. The issue of human security then becomes an international concern and a new security agenda after the cold war, triggering immediate intervention when the state failed to deliver basic protection and need for their citizen (Peace Security and Development Network, 2009).
While the discourse of fragile states has been widely known and becomes an international spotlight, there is no any fixed definition of fragile states, nor any agreed list of fragile states (Andersen, 2008). In fact, the term of fragile states is imprecise both historically and analytically. The criticism is addressed on the unrealistic expectation of the northern states that the solution of southern states to prevent violence and repression can only be achieved through the lesson learned from the European and American context (OECD/DAC discussion paper, 2008:15-16). Moreover, the definition of fragile states varies depend on the background of donors who define fragility of states; different on indicator used to measure fragility and on prioritized policies in overcoming the problems. For instance, the International Monetary Fund (IMF) put much emphasizes on the economic factors, whereas the United States Agency for International Development (USAID) provides definition more focuses on security dimension. Nevertheless, many actors increasingly refer to the definition formulated by Development Assistance Committee: "States are fragile where state structures lack political will and/or capacity to provide the basic functions needed for poverty reduction, development and to safeguard the security and human rights of their populations" (OECD/DAC, 2007:2). This definition then delineate that the fragility originates within the state and that state is the only actor who fully responsible and is obliged to overcome the problems.

The problem of fragile states is often thought around the state-centered term. Kaplan (2008), for example, argues that the sources of fragile states are rooted from two structural problems: political identity fragmentation and weak national institutions. These problems, as argued by Kaplan, hinder the attempts to create society cohesiveness and ultimately bring states to a highly unstable and a hard-reform political order. In addition to the state-centered logic, former President of the World Bank Group, Robert B. Zoellick (2008), argues that the ineffective and weak government, combined with corruption and insecurity, are the main characteristic of fragile states. This 
characteristic furthermore makes states unable to enhance economic growth and thus society is suffering from extreme poverty. However, the analysis and definition using the state centered term bring much weakness and flaws in apprehending the core problem of fragile states. Engberg-Pederen, Anderson and Stepputat (in Peace Security and Development Network, 2009) argue that analysis that pays much attention to state tend to ignore the fact that fragility also exist outside the state and that international phenomena contribute to the fragility of states.

Aside from the problem of definition and analysis of fragile states, common thought conceives that fragile states have major impact to their population, regional stability, and international community. Human security and development are not guaranteed in the fragile situation. The World Bank data shows that, as much as $36 \%$ of people in fragile states are living under poverty as well as $33 \%$ children is having no primary education. Protection of human rights also less in fragile states and even human rights abuses occurred widely since the state unable and unwilling to provide security and rule of law. This is furthermore triggering other more serious problems such as the flows of refugees, terrorism networks, illegal drugs trafficking and weapons trade, trans-border problem and international crime which all pose threat to regional and global security and development (The Netherland's Strategy, 2008).

\section{SECURITY-DEVELOPMENT NEXUS}

Given that humanitarian crisis and security problems are paramount in fragile states, international policies since the early 1990s had given much attention to the need of connecting security concern into development in overcoming the problem of fragile states. Major international organizations such as the World Bank, for instance, implemented the idea of 'security first' and of 'sustainable disarmament for sustainable development' in their project within postconflict peacebuilding process (Schwarz, 2005). It is also emphasized on the European Council Report on the Implementation of the European Security Strategy that "As the ESS [European Security Strategy] and the 2005 Consensus on Development have acknowledged, there cannot be sustainable development without peace and security, and without development and poverty eradication there will be no sustainable peace" (European Council Report on the implementation for the European Security Strategy, 2008:12). Moreover, reiterating the statement of former UN Secretary General, Kofi Annan, 'development and security are inextricably linked' in which extreme poverty problem can either threat society in and outside the state by the flows of refugee, civil conflicts, and illegal drug trafficking and weapons. The problems hence can only be overcome by meeting the Millennium Development Goals (in Stern and Ojendal, 2010). It is clear that the notion of security development nexus becomes prevalent in both national and international global policies making and is regarded as significance insight to fight against the problems of human insecurity.

The relationship between the two notions, security and development, merges into security development nexus is possible because of the contemporary security and development's concept have been broadened away from the traditional emphasize. The traditional concern of security has been shifted from the protection of state territorial integrity into the security and well-being of its population within the state's jurisdiction (McDougall, 2010). According to Barry Buzan (1983), the notion of security was broadened for three main reasons. First, security concern was shifted to other non-traditional issues due to the declining of tension and rivalry between superpowers. Second, the importance of resources as well as economic cooperation and interdependence led security concern to a new different perspective. Third, international attention to the problem within developing countries has recognized that the traditional concern of security is no longer relevant and thus should be widened beyond military issue encompasses various contemporary issues such as economic, environmental and political stability, and put more concern to individuals, regions, minority groups, etc.

Likewise, the notion of development has been 
broadened. The previous concept of development was perceived as obsolete and disappointed. From merely economic issues, the concept was then widened to cover institutions, property regimes, governance and prosperity of society. Moreover, the concept was also deepened by acknowledging the significance of regional integration, social capital, and human security (Bueger \& Vannesson, 2009). The security development nexus therefore suggests that attempts to overcome fragile states will need a long-term security-development policy based on strategies that are appropriate to those fragile states. The strategies should address the issue of economics (whether by reducing poverty and/or reducing inequality), human security and of strengthening institution. Much discourses of development are predominated by the paradigms that emerged from the international institutions such as World Bank, IMF, and from the major donors' interaction such as the Development Advisory Committee of the Organization for Economic Cooperation and Development (McDougall, 2010). The common objective of these institutions and donors are centered on creating sustainable development that can simultaneously enhance security in a broad term by meeting the Millennium Development Goals (European Consensus, 2005). In this context, fragile states entail international intervention through development aids and certain policies to arise from fragility. However, some measurements, policies, and aids are often too compelled and act as a method of rule. Stern and Ojendal (2010: 20) hold that security development nexus is adopted as 'technique of governmentality'. It is a technique aimed at governing and regulating the development of life through interrelated efforts such as the humanitarian assistance, the politics of aid and 'good governance' agenda. This technique, as argued by Stern and Ojendal, is furthermore applied through 'controlling, disciplining, 'uplifting' and regulating the 'dangerous', the unruly, the subalterns and the voiceless'. This however seems to delineate fragile states as backward or dangerous and thus international intervention needs to be done through certain taken-forgranted mechanisms as stated above.
In short, the concurrent broadening of the notion of security and development has led many issues to fall within the domains of these policy fields. The securitydevelopment nexus thereby provides a framework for the issue of fragile states. This nexus reflects a dual claim that security, on one side, is fundamental for alleviating poverty, and on the other side, that violence and conflict increasingly occur due to a lack of development. It affirms that security and development are inherently interconnected - one cannot be operated without the absence of the other. Moreover, the nexus also leads to a third claim implies that security is indivisible. It means that the problem of security and development in a particular part of the world can potentially affect the security and stability in other parts. Hence, attempt of maintaining security at home will imply Western government to undertake development abroad (Duffield, 2001; Beall et al., 2006, quoted in Andersen, 2008:10).

\section{DOES SECURITY DEVELOPMENT NEXUS GIVE USEFUL INSIGHT TO SECURITY AND HUMANITARIAN THOUGHT TO ARISE FROM FRAGILE STATE?}

Security-development nexus operated in term of the comprehensive governance agenda is apparently problematic, not least because the implementation of security-development nexus across the policy arenas (state-building and peacebuilding) failed to identify and to overcome the existing problem on the ground around and within fragile states. To resolve the problem of (human) security and development in fragile states, it is often framed through the spatial-temporal framework and furthermore this framework is used as the parameter of analysis of fragile states. The framework stresses on state-centered term to analyze insecurity and poverty and thus fragility is deemed as a condition rooted from this spatial unit of analysis. It also emphasizes on the temporal logic of development process in form of progressivity. It assumes that state can be liberated from insecurities and gain modernity (Shah, 2009:19).

The spatial analysis in state-centered term is often found on discussion and debate about fragile states. 
As outlined above, most insights and arguments recognize that weak and ineffective governments and institutions, as well as political fragmentation (which presumes that these all have been built by the state itself), lead states to fragility and thus conflict, poverty, and insecurity are flourishing and ultimately bring states to face the breakdown of law and order, civil war, human rights abuses, and extreme poverty (Freedman, 1993, quoted in Bilgin \& Morton, 2002:66). This analysis however is weak on addressing the important point of problem that is questioning, "who's failed the failed/fragile states?" This question must be asked because majority simply problematizes the intrinsic characteristic of fragile states, yet it rarely touches upon the colonial experience of these states and their positions in the global politico-economic structures which are significantly triggering, creating, and (re) producing insecurity and inequality throughout society (Bilgin \& Morton, 2002:66).

The past historical experience of fragile states, mostly developing states, was the experience of colonialism. The grand narrative of the colonial period is mainly about the history of injustice, insecurity, and inequality within the relationship between 'master' and 'slaves', and 'the ruler' and 'the ruled'. Injustice, insecurity, and inequality are the pattern in which the master ruled and served the slaves during the colonial period. These patterns in fact (re)produced through the establishment of certain colonial institutions solely aimed at preserving these patterns and thus strengthening the colonial rule and power throughout the colonies. Although by the early $19^{\text {th }}$ century these colonies fought and won for their independence from their colonial master, these patterns (inequality, injustice, and insecurity), instead of having declined, were in fact increasing in the following decades (postcolonial period) (Berger, 2006).

These patterns are preserved until the present time within social relations, between the state and civil society, which has been occupied by power hegemony of the Western world through international intervention over the non-Western world. Social relation explains the conception and relation between states and civil society. Here, the state is not understood as simply the government's apparatus operating within the 'public' sphere (political parties, military, government). Instead, it poses as part of the 'private' sphere of civil society (church, media, education). Civil society, according to Gramsci, "exerts a collective pressure and obtains objective results in the form of an evolution of customs, ways of thinking and acting, morality etc." (quoted in Bilgin \& Morton, 2002:71). Hence, it illuminates how the relational nature and identity of various different interests within civil society are constructed and thus leads to the inclusion of individuals within collective will and thereby "turning necessity and coercion into "'freedom"” (ibid). This form of social relations is the realm in which hegemony plays its role to maintain the domination and inequality. How Western power hegemony can penetrate into social relation is enabled by international intervention that is justified through annexation of western knowledge that constructs the representation of post-colonial states by labeling them as 'failed', 'rogue', 'fragile', or 'collapse' states. These kinds of labels, as argued by Bilgin and Morton, are used as the representation of post-colonial states that enable certain policies to be enforced as an attempt for serving economic, political, and security interest of those who employed. The intervention then serves the interest of hegemonic power to be persisted and to reproduce patterns of domination, inequality, and as well as insecurity over society.

Furthermore, once intervention has penetrated and hegemony has been established within a social relation of certain states, it cooperates with elite political ruling and civil society in pursuing the ideological goals and interest of liberal modern states through state building project. This is moreover exposing the failure of state building in relation to the security development nexus in fragile states. The goal is merely underpinned by the elusive temporal logic of progressivity, presuming that prosperity, welfare, and security can be ensured once states are reconstructed into a modern liberal state in term of democratizing states' institutions, adopting liberal free trade mecha- 
nism and privatization, and competing within the global market. However, this model of progressivity has brought states to face the paradox of globalized development, which in turn maintaining the persistence of inequality and insecurity throughout society.

According to Cerny (1997), states within the dynamics of political globalization are competing among others, rather than cooperating. At the same time, the homogenization of market adds more pressure to states, creating a growing tension between economic globalization and embedded state/society. Moreover, this competition ultimately leads states to an overload exploitation of natural resources that in turn create environmental degradation, human insecurity, and inequality. The notion of security-development nexus therefore casts a doubt to an attempt of states to rise from their fragility.

\section{CONCLUSION}

Security-development nexus based on the spatialtemporal framework has precisely failed to identify the crucial problem of states seeking to rise from their fragility. Rather than enabling state and society to gain prosperity, welfare, and security, it is indeed maintaining and reproducing the pattern of insecurity and inequality throughout society. Hence, attempt to resolve the problem of fragile state will need to broaden the analysis out of the state-centered term and spatial-temporal framework by considering the global power relations and historical experience of inequality and insecurity within states.

\section{REFERENCES}

Andersen, L 2008, 'Fragile states on the international agenda, DIIS REPORT 2008:11, pp.7-20.

Berger, MT 2006, 'From nation-building to state-building: The geopolitics of development, the nation-state system and the changing global order', Third World Quarterly, Vol. 27, No. 1, pp. 5-25.

Bilgin, P and Morton, AD 2002, 'Historicising representations of 'Failed States': Beyond the Cold-War annexation of the social sciences?', Third World Quarterly, Vol. 23, No. 1, pp. 55-80.

Bueger, C and Vennesson, P 2009, 'Security, development and the EU's development policy', European University Institute - Robert Schuman Centre for Advanced Studies April 2009, pp. 145.ESILIENCE
Cerny, PG 1997, 'Paradoxes of the competition state: The dynamic of political globalization', Government and Opposition, 32(2): 251274.

Kaplan, S 2008, 'Fixing fragile states', Policy Review; Dec 2008/Jan 2009; 152; ProQuest

pg. 63.

McDougall, D 2010, 'The security-development nexus: Comparing external interventions and development strategies in East Timor and Solomon Islands', Asian Security, 6:2,170-190.

OECD/DAC Discussion Paper, 'Concepts and dilemmas of state Building in fragile situations', OECD-2008, pp.1-82.

Peace Security and Development Network Working Paper I, 'The Fragile states discourse unveiled', Utrecht, 28 May 2009.

Schwarz, R 2005, 'Post-conflict peace building: The challenges of security, welfare, and representation', Security Dialogue, 36(4): 429-446.

Shah, K2009, 'The failure of state building and the promise of state failure: Reinterpreting the security-develoment nexus in Haiti', Third World Quarterly, 30(1): 17-34.

Stern, M and Öjendal, J 2010, 'Mapping the security—development nexus: Conflict, complexity, cacophony, convergence?', Security Dialogue, 41: 5 .

The Netherlands' strategy 2008-2011, 'Security and development in fragile states', November 2008, pp.1-48.

Wallis, J 2012, 'A liberal-local hybrid peace project in action? The increasing engagement between the liberal and the local in Timor Leste,' Review of International Studies, Published online February 12 2012:1-27

Zoellick, RB 2008, 'Fragile states: Securing development,' Survival: Global Politics and Strategy, 50:6, 67-84. 